\title{
Evaluation the effect of placenta on some clinical biochemical parameters during different reproductive periods in New Zealand white female rabbits.
}

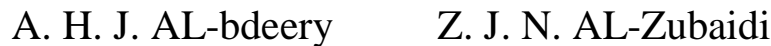 \\ Coll. of Vet. Med.-Univ. of Al- Qadisyia
}

\begin{abstract}
The current study was conducted to evaluate the effect of different reproductive periods on some biochemical parameters (ALP, ALT, AST and GGT) in New Zealand white female rabbits. The study was carried out in the animal house of the college of veterinary medicine in Al- Qadisyia university on 21 female New Zealand white rabbits, the animals were divided to 3 groups each group contain 7 rabbits: group A as control non-pregnant rabbits group B were pregnant rabbits and final group $\mathrm{C}$ were lactating female rabbits. Fresh blood samples (4 ml) were collected and centrifuged to obtained serum, then Reflotron apparatus was used for estimation of some enzymes (ALP,ALT, AST and GGT) in all groups of experiment. The results of group A revealed that the means of (ALP, ALT, AST and GGT) were (44.54, 45.52, 20.74 and 6.08) U/L respectively, while the means of enzymal levels in group B were (105.9, $48.08,22.68$ and 6.8) U/L respectively, and the means of enzymal levels in group C were (49.9, 46.21, 21.84 and 6.72) U/L respectively. The levels of ALP in group B showed significant increase $(\mathrm{P}<0.01)$ as compared with $\mathrm{A}$ and $\mathrm{C}$ groups, while there no significant increment among sera of three groups levels of (ALT, AST and GGT).
\end{abstract}

Keyword: Placenta, clinical biochemical, reproductive, periods, rabbit

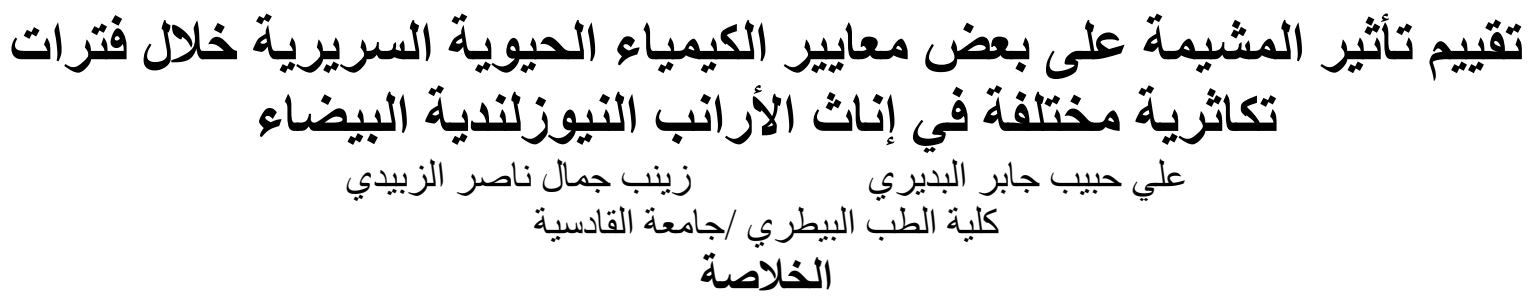

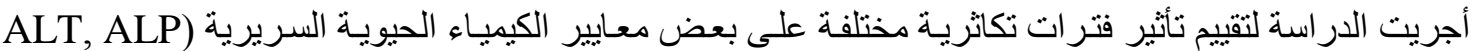

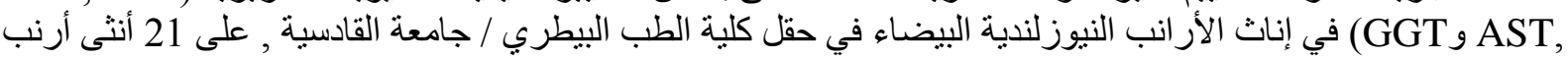

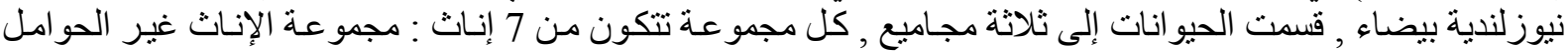

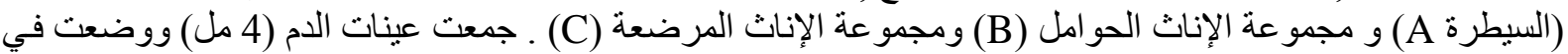

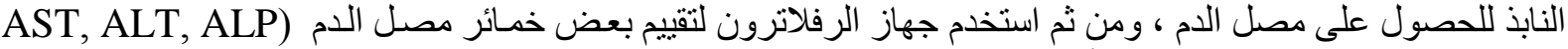

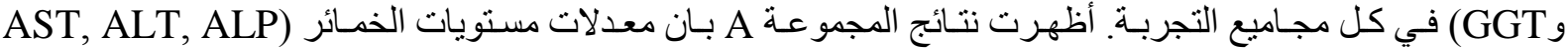

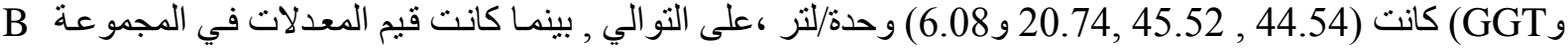

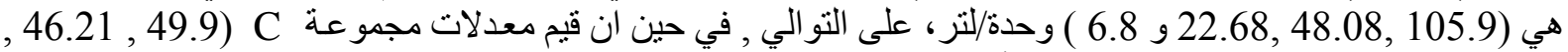

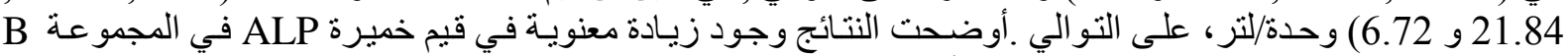

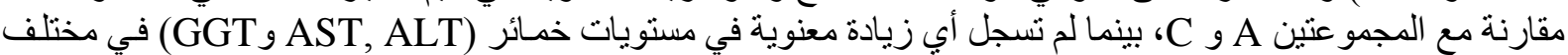

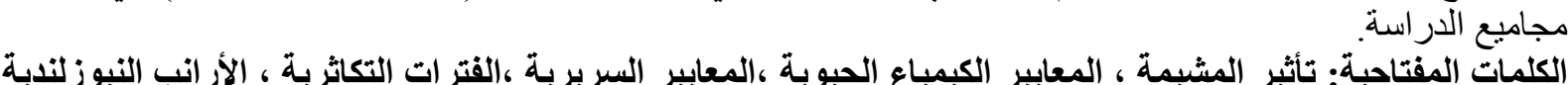
البيضاء.

\section{Introduction}

The normal reproductive periods that occur in females play an important role in hormonal and enzymal activity (1). The pregnancy is a normal physiological events, associated with normal physiological changes that aid the nutrition and survival of fetus $(2,3)$. Placenta considered an important specialized tissue controlling pregnancy and parturition in females (4). Some enzymes are found in more than one site such as found both in the cell sap and in the mitochondria as Aspartate aminotransferase, while alanine aminotransferase is confined to the cell sap 
through slight cell damage tends to release only the enzymes in the soluble fraction of the cell (AST) whilst necrotic lesions which also affect the mitochondria release both types (AST \& ALT) (5). Elevated values of gamma-gluamyltransferase (GGT) are caused by damage to cellular membranes which lead to cellular regeneration or enhanced synthesis as a result of induction of the biotransformation enzyme system, this enzyme is lack of specificity for the diagnosis of hepatobiliary disease because its found in hepatocytes, cholangiocytes, kidney, pancreas, epididymis, heart, lung, intestine, bone marrow, salivary glands, thymus, spleen and brain (6). Alkaline phosphatase (ALP) is a membrane-bound enzyme found in a wide variety of tissues, the enzyme is known to have phosphoprotein phosphatase and transphosphorylation activity and might have an important role in bone mineralization, but its function in the other tissue is not known (7).

\section{Materials and methods}

This study was carried out on 21 New Zealand white female rabbits, for detection of effect of placenta on some biochemical parameters (alkaline phosphatase (ALP), alanine aminotransferase (ALT), aspartate aminotransferase (AST) and gammagluamyltransferase (GGT), during different reproductive periods in New Zealand White female rabbits. Twenty one blood samples were collected from the female rabbits via ear vein $(4 \mathrm{ml})$, then put in sterile glass test tube with slope position in fridge under $4 \mathrm{C}^{\circ}$ for 2 hours then centrifuged (3000rpm) for 15 mints, sera were collected by sterile pipette to put in sterile epindroff tube to examine immediately by Reflotron apparatus (made by Roche - Germany ).

\section{Experimental design:}

The animals of study divided into 3 groups (A, B and C ), each group included 7 animals . Group A which have non-pregnant animals and considered as control group , group B have pregnant animals ( 20 days of gestation) and group $\mathrm{C}$ have lactating animals ( 20 days after delivery ).

\section{Estimation of enzymal levels:}

Enzymal levels were measured by using Reflotron apparatus according to use of
Reflotron analyzer in veterinary medicine (8).

\section{Statistical analysis:}

The results analysis statistically according to ANOVA tests by using SPSS under probability 0.01 for evaluation the results (9).

\section{Results and discussion}

The results showed that means of ALP levels in all experimental animals (A, B and C) were $(44.54,105.9$ and 49.9) U/L respectively (table:1; figure:1). The peack levels were (48.8, 113.1 and 53.0) U/L respectively, while the lowest levels were (41.6, 98.0 and 47.0) U/L respectively. Group B recorded a significant increment $(\mathrm{p}$ $<0.01$ ) in the level of enzyme compared with other two groups and there is no significant increment between group $\mathrm{A}$ and $\mathrm{C}$, this increment of enzymal level in pregnant female rabbits (group B) resulted from secretion of this enzyme from placenta during pregnancy and this accord with $(10,11,12)$ this enzyme increase during pregnancy also agreed with(13) who found alkaline phosphatase (ALP) increased during pregnancy due to secretion from placenta (produced by the syncytiotrophoblast) as well as agreed with (14) who found that alkaline phosphatase (ALP) can produce from liver, bone, kidney, small intestine and placenta . This result was compatible with $(15,16)$ who mentioned this enzyme will decrease after delivery .The results revealed that means of enzymal levels of ALT in sera of all animals ( A , B and C) were (45.52, 48.08 and 46) U/L respectively, while the levels of AST were $(20.74,22.68$ and 21.84) U/L respectively and for GGT were $(6.08,6.8$ and 6.72) $\mathrm{U} / \mathrm{L}$ respectively .The highest levels of ALT in sera of all animals were (47.6, 49.7 and 48.2) U/L respectively and the levels were $(24.3,26.2$ and 25.4) U/L respectively of AST, while the levels of GGT were $(7.7,8.9$ and 8.7$) \mathrm{U} / \mathrm{L}$ respectively, where as the lowest levels of ALT were (43.2, 46.9 and 44.5) U/L respectively and the levels of AST were (18.1, 19.4 and 19.0) U/L respectively, while GGT levels recorded (4.7, 5.5 and 5.4) U/L respectively .The statistical analysis among enzymal levels of all groups revealed there were no significant 
increment (tables: 2,3 \& 4; figures: 2,3\&4), and this accord with (11) who mentioned that these enzymes (ALT,AST and GGT) remain in normal references range during pregnancy and these results agreed with(17) that indicate were no significant differences between concentration of ALT and GGT in pregnancy and early lactation period in mares . Also compatible with the results that found by $(18,19)$ that revealed levels of ALT, AST and GGT unchanged during pregnancy. This result contradicted with (20) who recorded an increment in levels of these enzymes and these belong administration of pesticides toxicities which effect on the liver lead to increase of these enzyme, and also not agreed with the result reached by (10) who referred that ALT, AST and GGT will increase during pregnancy and this may be due to pathologic effected.

Table (1): The Concentration of ALP U/L in the serum of experimental animals .

\begin{tabular}{|c|c|c|c|c|}
\hline \multirow{2}{*}{ animals } & \multirow{2}{*}{ No. of animals } & \multicolumn{3}{|c|}{ Concentration of ALP U/L } \\
\cline { 3 - 5 } & & High level & Medium \pm SE & Low level \\
\hline NP. (A) & 7 & $48.8^{\mathrm{a}}$ & $44.54 \pm 1.315^{\mathrm{a}}$ & $4^{\mathrm{a}} .6^{\mathrm{a}}$ \\
\hline P. (B) & 7 & $113.1^{\mathrm{b}}$ & $105.9 \pm 3.248^{\mathrm{b}}$ & $98.0^{\mathrm{b}}$ \\
\hline L. (C) & 7 & $53.0^{\mathrm{a}}$ & $49.9 \pm 1.029^{\mathrm{a}}$ & $47.0^{\mathrm{a}}$ \\
\hline
\end{tabular}

Different letters denote a significance difference $(\mathrm{P}<0.01)$.

Table(2):The Concentration of ALT(GPT)U/L in the serum of experimental animals.

\begin{tabular}{|c|c|c|c|c|}
\hline \multirow{2}{*}{ animals } & \multirow{2}{*}{ No. of animals } & \multicolumn{3}{|c|}{ Concentration of ALT(GPT) U/L } \\
\cline { 3 - 5 } & & High level & Medium \pm SE & Low level \\
\hline NP. (A) & 7 & $47.6^{\mathrm{a}}$ & $45.52 \pm 0.779^{\mathrm{a}}$ & $43.2^{\mathrm{a}}$ \\
\hline P. (B) & 7 & $49.7^{\mathrm{a}}$ & $48.08 \pm 0.488^{\mathrm{a}}$ & $46.9^{\mathrm{a}}$ \\
\hline L. (C) & 7 & $48.2^{\mathrm{a}}$ & $46 \pm 0.703^{\mathrm{a}}$ & $44.5^{\mathrm{a}}$ \\
\hline
\end{tabular}

Similar letters denote a not significance difference $(\mathrm{P}<0.01)$.

Table(3):The Concentration of GOT(AST)U/L in the serum of experimental animals.

\begin{tabular}{|c|c|c|c|c|}
\hline \multirow{2}{*}{ animals } & \multirow{2}{*}{ No. of animals } & \multicolumn{3}{|c|}{ Concentration of GOT(AST) U/L } \\
\cline { 3 - 5 } & & High level & Medium \pm SE & Low level \\
\hline NP. (A) & 7 & $24.3^{\mathrm{a}}$ & $20.74 \pm 1.03^{\mathrm{a}}$ & $18.1^{\mathrm{a}}$ \\
\hline P. (B) & 7 & $26.2^{\mathrm{a}}$ & $22.68 \pm 1.445^{\mathrm{a}}$ & $19.4^{\mathrm{a}}$ \\
\hline L. (C) & 7 & $25.4^{\mathrm{a}}$ & $21.84 \pm 1.246^{\mathrm{a}}$ & $19.0^{\mathrm{a}}$ \\
\hline
\end{tabular}

Similar letters denote a not significance difference $(\mathrm{P}<0.01)$.

Table(4): The Concentration of (GGT) U/L in the serum of experimental animals .

\begin{tabular}{|c|c|c|c|c|}
\hline \multirow{2}{*}{ animals } & \multirow{2}{*}{ No. of animals } & \multicolumn{3}{|c|}{ Concentration of GGT U/L } \\
\cline { 3 - 5 } & & High level & Medium \pm SE & Low level \\
\hline NP. (A) & 7 & $7.7^{\mathrm{a}}$ & $6.08 \pm 0.498^{\mathrm{a}}$ & $4.7^{\mathrm{a}}$ \\
\hline P. (B) & 7 & $8.9^{\mathrm{a}}$ & $6.8 \pm 0.591^{\mathrm{a}}$ & $5.5^{\mathrm{a}}$ \\
\hline L. (C) & 7 & $8.7^{\mathrm{a}}$ & $6.72 \pm 0.564^{\mathrm{a}}$ & $5.4^{\mathrm{a}}$ \\
\hline
\end{tabular}

Similar letters denote a not significance difference $(\mathrm{P}<0.01)$.

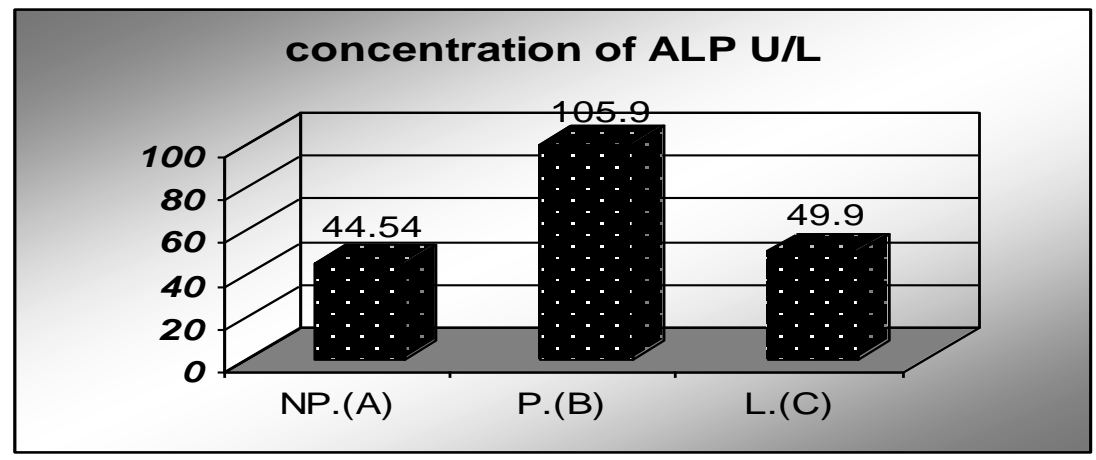

Fig. (1) : The Concentration of ALP U/L in the serum of experimental animals . 


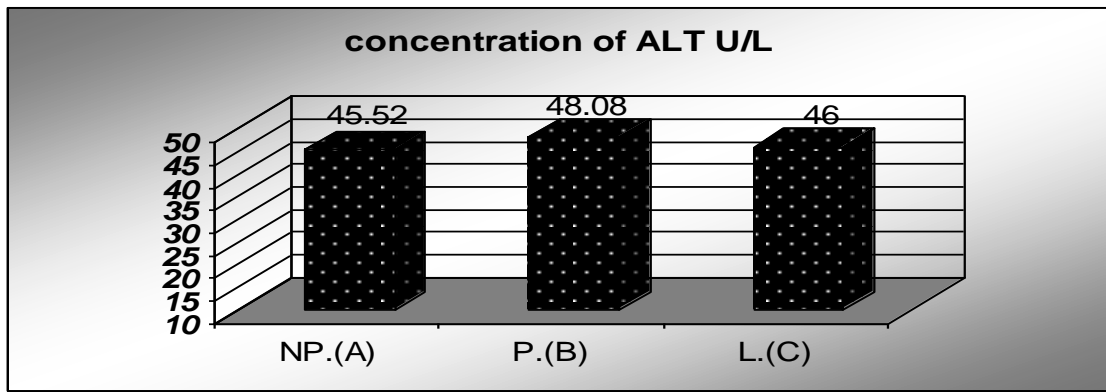

Fig. (2) : The Concentration of ALT (GPT) U/L in the serum of experimental animals .

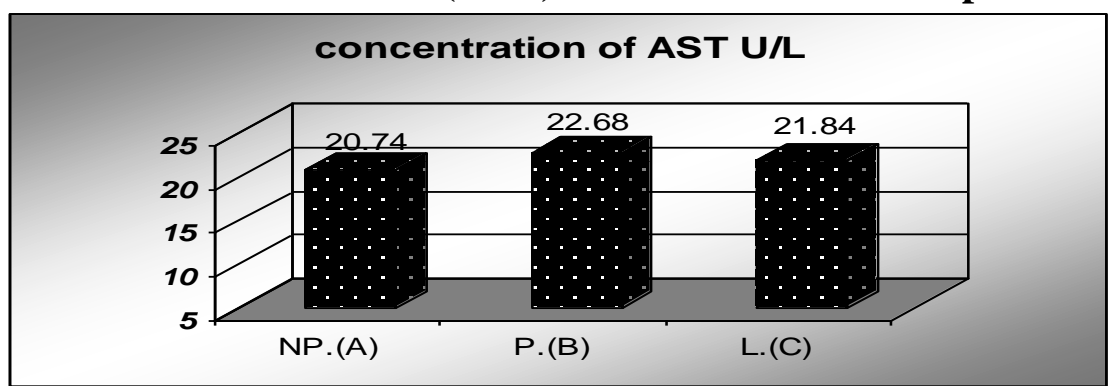

Fig. (3) : The Concentration of GOT (AST) U/L in the serum of experimental animals .

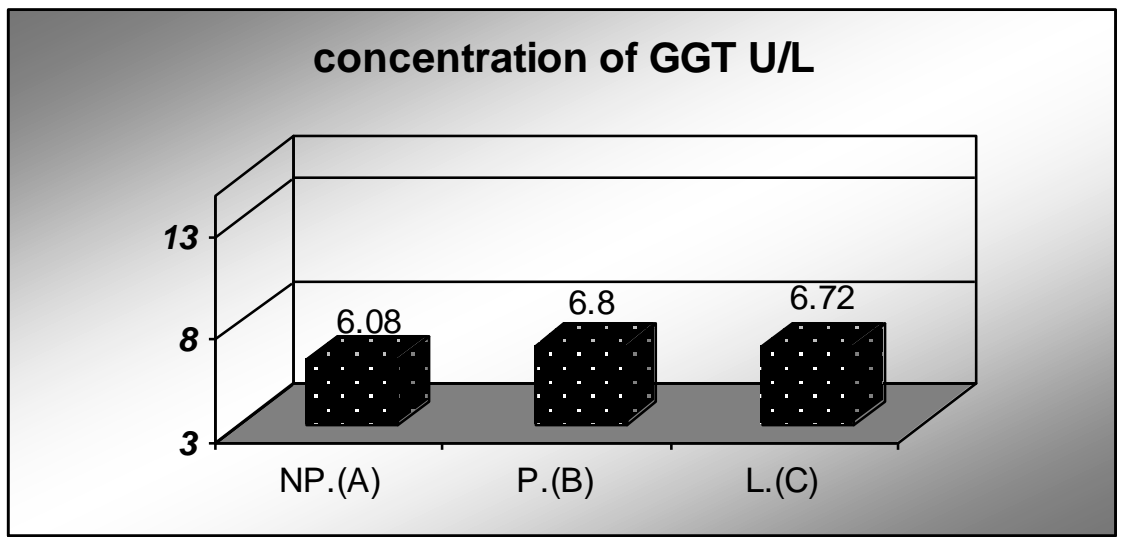

Fig. (4) : The Concentration of (GGT) U/L in the serum of experimental animals .

\section{References}

1. Senger, P.L. (2003). Pathway to Pregnancy and Parturition . $2^{\text {nd }}$ edition. Printed in the USA. Addition copies current conception ,Inc. 2005 .Chapters ; 7,14\&15 : Pp.144,304\&326.

2. Tran, H. A. (2005) . Biochemical tests in pregnancy . Australian prescriber ; 28(4):98-101.

3. Salman, M.I. (2009) . Changes in liver functions tests during pregnancy. J. of al-anbar Univer. Pure Sci. 3(1).

4. Noakes, D.E. ; Parkinson, T.J. \& England, G.C. (2009) . Veterinary Reproduction and Obsteterics . 9 edition . Saunders Elsevier . Part 2 ;Pregnancy \& parturition ; Pp.61-207.

5. Wieme, R. J. and Demeulenaere, L. (2013). Enzyme assays in liver disease. J. clin. Path.;24(4): 51-59 .

6. Kuntz E. \& Kuntz, H.D.(2006). Laboratory diagnostics. In: Hepatology, principles and practice. $2^{\text {nd }}$ edition. Heidelberg : Springer Verlag. Pp: 78-112.

7. Ali, A. T. ; Paiker, J. E. and Crowther, N. J. (2006) . The Relationship Between Anthropometry and
Serum Concentrations of Alkaline Phosphatase Isoenzymes, Liver Enzymes, Albumin, and Bilirubin. Am J Clin Pathol.;126:437-442 .

8. Lopes-Pereira C. M.; Harun, M.; Schmidtova, D. Timane, I.; Mabasso, M.; Otto, F. and Bogin, E. (1992) .Use of the Dry Chemistry "Reflotron" Blood Analyzer under Outdoor-Field Conditions in Veterinary Medicine . Eur. J. Clin. Chem. ; 34:231-235.

9. Petrie, A. \& Watson, P. (2004). Statistics for veterinary and animal science. Illustrations prepared by Alexander Hunte . Printed and bound in Great Britain . By T.J. International Ltd, Padstowy Cornwall.

10. Alonso, A.G.(2006). Effect of pregnancy on preexisting liver disease physiological changes during pregnancy. Annals of Hepatology, 5(3):184-186.

11. Bacq, y. ; Zarka, O. ; Brechot , J. ; Mariotte , N. ; Vol, S. ; Ticher, S. and Weill, J. (1996) . Liver function tests in normal pregnancy : A prospective study of 103 pregnant women and 103 matched controls. Hepatology; 23(5):1030-1034 . 
12. Okesine, A. B.; Donaldson, D.; Lascelles , P. T. , and Morris , P. (1995) . Effect of gestational age on levels of serum alkaline phosphatase isoenzymes in healthy pregnant women. International J. Gynecolo. \& Obstet.; 84(1):25-29.

13. Bashiri, A. ; Katz , O.; Maor, E.; Sheiner, E.; Pack , I. and Mazor , M. (2007) . Positive placental staining for alkaline phosphatase corresponding with extreme elevation of serum alkaline phosphatase during pregnancy. Archive of Gynecolo. \& Obstet.; 275(3):211-214.

14. Delluc, C.; Costedoat-Chalumeau, N.; Saadoun, D. ; Vauthier-Brouzes, D. ; Wechsler, B. and Piette, J. (2008). Elevation of alkaline phosphatase in a pregnant patient with antiphospholipid syndrome: Hellp syndrome or not ? Oxfo. J. Med. Rheumatology; 47(4):554-555 .

15. Wojcicka-Bentyn , J. ; Czajkowski , K. ; Sienko , J. ; Grymowicz , M. and Bros , M. (2003). Extremely elevated activity of serum alkaline phosphatase in gestational diabetes : a case report . American J. of Obstet. \& Gynecolo.; 190(2):566567.

16. Vongthavaravat, V.; Numberger , M.; Balodimos , N. Blanchette , H. ; Koff , R. S. ; Framingham , and Massachusetts , S. (2000) . Isolated elevation of serum alkaline phosphatase level in an uncomplicated pregnancy : A case report . American J. of Obstet. \& Gynecolo.; 183(2):505506 .

17. Milinkovic-Tur , S. ; Peric , V.; Stojevic , Z.; Zdelar-Tuk , M. and Pirsljin, J. (2005). Concentrations of total proteins and albumins, and AST, ALT and GGT activities in blood plasma of mares during pregnancy and early lactation . Vet. Arhiv. ; 75(3):195-202.

18. Mitra , A.K. ; Patki , P.S. and Mitra, S.K. (2008) . Liver disorders during pregnancy and their management . The Antiseptic ; 105(4):193-196 .

19. Carter, J. (1990). Liver function in normal pregnancy . Aust. $N Z$ J. Obstet. Gynecolo.; 30(4):296-302 .

20. Zama , D. ; Meraihi , Z. ; Boubekri , N.; Amrani , A.; Tebibel, S. and Baal, N. (2005). Assessment of the changes in some diagnostic enzymes and other parameters in wister albine rats treated with pesticides during gestation. Sciences \& Technologic C-N 23, juin , pp. 51-56 . 